\title{
Trace element features of modern black, gray and clear smokers and their ancient analogues
}

\author{
V.V. MASLENNIKOV ${ }^{1,2}$, N.R. AYUPOVA ${ }^{1,2}$, \\ S.P. MASLENNIKOVA ${ }^{1}$, R.R.LARGE ${ }^{3}$, G.A. TRETYAKOV ${ }^{1}$ \\ AND L.V. DANYUSHEVSKY ${ }^{3}$ \\ ${ }^{1}$ South Urals Federal Research Center of Mineralogy and \\ Geoecology of the UB RAS, Miass, 456317, Russia \\ (correspondence: mas@mineralogy.ru) \\ ${ }^{2}$ South Urals State University, Miass, 456318, Russia \\ ${ }^{3}$ CODES ARC Centre of Excellence in Ore Deposits, \\ University of Tasmania, Hobart, Australia
}

A variety of modern black, gray, and clear smokers (Pacific and Atlantic oceans) and their very well preserved fossil vent analogues from the Urals, Rudniy Altai, Pontides and Hokuroko massive sulfide deposit show systematic trace element distribution patterns across chimneys. Frequently, chalcopyrite is enriched in $\mathrm{Se}, \mathrm{Sn}, \mathrm{Bi}, \mathrm{Co}, \mathrm{Mo}$, and Te. The trace elements, except $\mathrm{Sn}$ and Mo, decrease in the range from black to gray and clear smokers including their ancient analogues. Sphalerite in the conduits and the outer chimney wall contains elevated $\mathrm{Sb}, \mathrm{As}, \mathrm{Ag}, \mathrm{Pb}, \mathrm{Co}, \mathrm{Ga}, \mathrm{Ge}, \mathrm{In}, \mathrm{Sn}$, $\mathrm{Mn}, \mathrm{U}$, and $\mathrm{V}$. The highest concentrations of most trace elements are found in colloform pyrite within the outer wall of the chimneys, and likely result from rapid precipitation in high temperature-gradient conditions.

Host rocks also influence on trace element assemblages in chalcopyrite of modern and ancient chimneys: ultramafic (high Se, Sn, Co, Ni, Ag and Au) - mafic (high Co, Se, Mo and low $\mathrm{Bi}, \mathrm{Au}$ and $\mathrm{Pb}$ ) - bimodal mafic (high $\mathrm{Te}, \mathrm{Au}, \mathrm{Ag}$, $\mathrm{Bi}, \mathrm{Pb}, \mathrm{Co}$, moderate $\mathrm{Se}$, and variable $\mathrm{As}$ and $\mathrm{Sb}$ ) - bimodal felsic (high $\mathrm{As}, \mathrm{Sb}, \mathrm{Mo}, \mathrm{Pb}$, moderate $\mathrm{Bi}$, and low $\mathrm{Co}$, Te and $\mathrm{Se}$ ). In the same range in sphalerite, the contents of $\mathrm{Bi}, \mathrm{Ga}$, $\mathrm{Pb}, \mathrm{In}, \mathrm{Ag}, \mathrm{Au}$ and $\mathrm{Sb}$ increase versus $\mathrm{Fe}, \mathrm{Se}, \mathrm{Sn}$ and $\mathrm{Co}$ while $\mathrm{Ni} / \mathrm{Co}$ ratios increase in pyrite. These changes coincide also with maturity of seawater interactions with host rocks: $\mathrm{Co}, \mathrm{Fe}, \mathrm{Cu}$ contents are elevated in immature hydrothermal systems while $\mathrm{Pb}, \mathrm{Tl}, \mathrm{Sb}$, and $\mathrm{Au}$ are higher in mature systems. In chimney formed by depleted hydrothermal fluids, the most trace elements are concentrated in sphalerite and pyrite versus chalcopyrite (Hokuroko type). The foot wall organic-reach sediments and carbonaceous rocks can influence on maturity of hydrothermal system and consequently on geochemistry of chimneys where incompatible trace elements are retained. 